\title{
曼下困難で判明した重症筋無力症例
}

\author{
平瀬 博之・松崎 勉 $・$ 上野 員義・黒野 祐一
}

\section{A Case of Myasthenia Gravis Presenting with Dysphagia}

\author{
Hiroyuki Hirase, Tsutomu Matsuzaki, Kazuyoshi Ueno and Yuuichi Kurono \\ (Kagoshima University)
}

\begin{abstract}
Dysphagia is generally classified into two types, static and dynamic disorders, depending on the cause. Usually, dysphagia is caused by static disorders such as pharyngo-esophageal stenosis or esophageal obstruction caused by tumors or foreign bodies. In contrast, it is unusual to see patients with dysphagia related to dynamic disorders such as neurologic or muscular diseases. We present here a patient with myasthenia gravis whose chief complaint was dysphagia. The patient was a 71year-old female who complained of dysphagia immediately after meals, and was suspected to have a foreign body in her esophagus. Upon examination at our department, no esophageal foreign bodies were observed by endoscopy, but fluoroscopic examination using a contrast medium showed an abnormality in the hypopharynx. After hospitalization for further investigation, she suddenly developed aspiration pneumonia and respiratory arrest. Her lung function was improved by ventilation. Based on these events, a systemic neurological disorder underlying her dysphagia was strongly suspected. After referral to a neurologist, the patient was diagnosed with myasthenia gravis 12 days after her hospitalization.
\end{abstract}

Key words : dysphagia, static disorders, dynamic disorders, myasthenia gravis

はじめに

㱬下運動は第 1 相から第 3 相までの 3 相に分類され， それぞれの相に拉ける様々な障害によって嚥下困難が生 じる.曣下困難は一般に静的障害と動的障害に分けられ, 前者には癌などの腫瘤病変による咽頭・食道の狭窄, 異 物による咽頭・食道の閉塞が挙げられる. 後者の原因と しては神経・筋の異常，その他強皮症など膠原病に基づ く食道病変があるが，日常臨床でこうした病変に遭遇す ることはまれであり，その診断に苦慮することが少なく ない，今回我々は，食事中突然嚥下困難を来し，当初食 道異物が疑われたが，その後の精査によって重症筋無力 症と診断された一例を経験したので若干の文献的考察を 加壳て報告する.

\section{症例}

症例 : 71歳, 女性.

主訴 : 燕下困難.

既往歴：特記事項なし.

現病歴: 1995年 6 月 9 日，牛肉を摂食直後より突然與 下困難が出現した。水分摂取は問題なかったが固形物の 嚥下が次第に困難となり，6月13日近医耳鼻咽喉科を受 診し食道異物を疑われ当科受診勧められるも放置した. その後さらに水分摂取も困難となってきたため，6月16 日当科を紹介受診となった。

初診時所見：嚥下困難を訴えるも嚥下痛はない。間接 喉頭鏡検査にて咽頭・喉頭ともに特に異常所見を認めず， 鼻咽腔ファイバースコープにて食道第 2 狭窄部まで観察 するも異常所見を認めなかった。画像診断では頸部 CRX-P で特に異常所見を認めなかったが，頸部食道造 


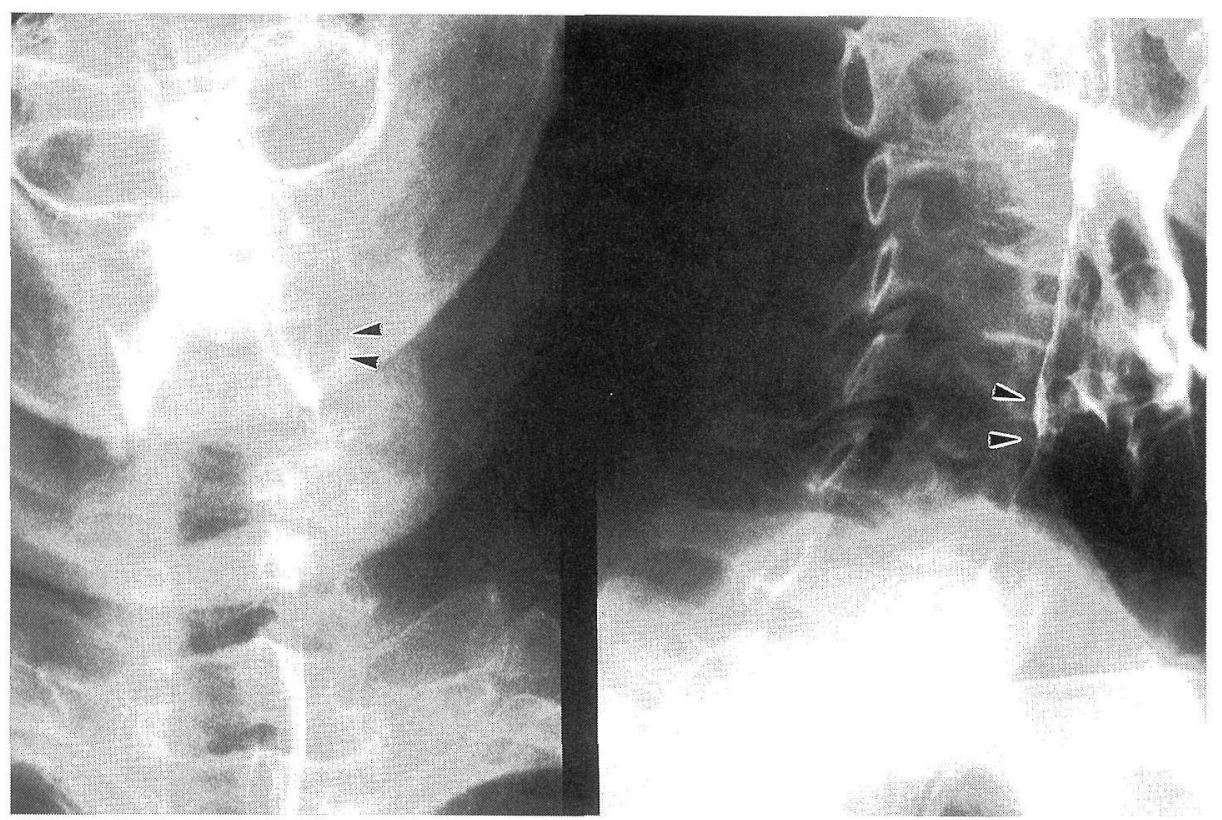

図 1 頸部食道造影所見

下咽頭左梨状陥凹部に腫瘤様病変を認める.

影にて下咽頭左梨上陥凹に腫瘤様病变を疑わす所見(図 1)を認めたため，精査目的にて入院となった。

入院時所見：翌 6 月 17 日，当科へ歩行入院した．入院 時の全身所見では, 体温, 脈拍, 血圧は正常で呼吸状態 も異常を認めず，意識レベルは 3-3-9 度方式で 1 - 1 で正常であった。しかしながら，応答は鈍く，顔貌は眼 瞼下垂気味(図 2 )で, 四肢に麻㽻は認めないものの, 全

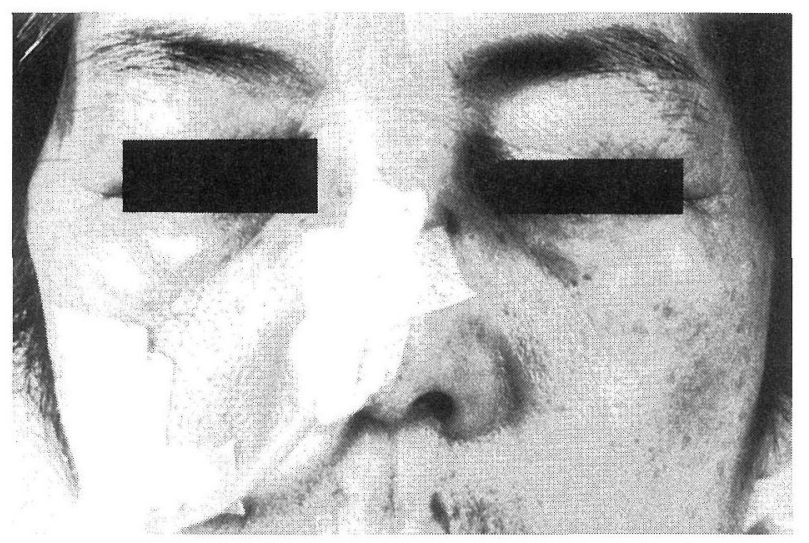

図 2 症例顔貌

眼瞼下垂，無力顔貌を呈している.

(重症筋無力症の確定診断後撮影されたもの)
身の脱力感が強い印象を受けた。臨床検査に打いては, 末血拉よび生化学検査上特に異常所見は認めなかったも のの，尿中ケトン体が $(3+)$ であり発症後 7 日間の摂食 障害に起因寸るものと思わ机た。心電図, 胸部 X-P, 動 脈血ガス分析では異常を認めなかったが，呼吸機能検査 にて肺活量 $1030 \mathrm{ml}$ ，\%肺活量 $45 \% ， 1$ 秒率 $74 \%$ という 拘束性パターンを示した.

入院後経過：まず低栄養による細胞内飢餓の改善目的 で，入院当日経鼻胃管チューブを挿入し，経管栄養を開 始した. 1 時間後, 咳嗽に引き続き口腔内一の経管栄養 剂の逆流, 喘鳴を生じ, その時点の動脈血ガス分析で, $\mathrm{PaO}_{2}$ の著明な低下を認めた。胸部 X-P にて右中葉の無 気肺像の所見が得られたため, 頸部から胸部にかけての CT 撮影を施行したところ, 右主気管支以下の広範な狭 窄像がみられ，気管支内異物に上る與下性肺炎と診断さ れた。な报，この際の CT にて下咽頭には頸部食道造影 で疑われた腫瘤病変はなく, さらに頸部食道や緹隔内に も腫瘍性病変や異物のないことが確認された。気道確保 のため直ちに気管切開施行したらえで，気管支ファイ バー検査を行なったが，気管支内には誤與したと思われ

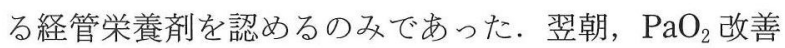
目的でベンチレーター接続のら光持続的気道陽圧 
(CPAP) モードにて自発呼吸下に管理した。ところが， 夕方より突然の意識障害を伴う自発呼吸停止を認めるよ らになってきたため周期的間欠的強制換気 (SIMV) モー ドへの変更を余儀なくされた．その後，6月23日，入院 後第 7 病日より人工呼吸器からの離脱を開始し, 第 10 病 日である 6 月27日には完全に自発呼吸管理とする事がで きた. 同日施行した頭部 CT 撮影では, 軽度の大脳萎縮 を認めたが，虚血性変化は認めなかった．以上の経過か ら, 燕下困難和よび䛊嚥, その後の呼吸停止などの一連 の原因として神経因性のものが強く疑われたため，6月 29 日，入院後第 12 病日，神経内科を紹介受診した。その 結果, テンシロンテスト陽性, 筋電図上鼻筋, 小指外転 筋, 僧帽筋でのウェニング陽性, 抗アセチルコリンレセ プター抗体陽性などの所見が得られ, 重症筋無力症と診 断された1)（表 1 ）。な拉，本症例は診断確定後の 7 月 4 日神経内科に移り，ステロイドを中心とした保存的療法 にて加療が開始された。転科後 3 日目には経鼻胃管チ ューブ管理下に経口摂取訓練を開始可能となり，6日目
には経鼻胃管チューブ抜去することが可能となった．そ の後は神経内科外来にて保存的加療を継続しているが, 現在まで與下困難および䛊鱟は認めず経過良好である.

\section{考察}

耳鼻咽喉科・頭頸部外科領域において曣下困難を訴え る患者は少なくない。しかし，一言に曣下困難と言って も原因疾患は非常に多岐に渡って扣り診断は容易ではな い. 嚥下は 1 つの運搬作業で, 食塊を搬送する通路と食 塊を動かす動作が必要なことから，與下障害は通路その ものの静的状態の異常 (腫瘤, 狭窄, 瘦孔等)によって起 こる静的障害と, 運搬動作の異常 (神経 - 筋系の機能異 常)による動的障害に区別される23) (表 2 ). 静的障害に ついてはさほど診断に苦慮することはないと考えるが， いわゆる神経筋系の障害ならびに全身疾患の一部分症で ある動的障害に括いては診断が難しく，時には“異常な し”と診られることが少なくない、今回我々が経験した 重症筋無力症も動的障害を起こす一疾患である.

\section{表 1 重症筋無力症診断基準}

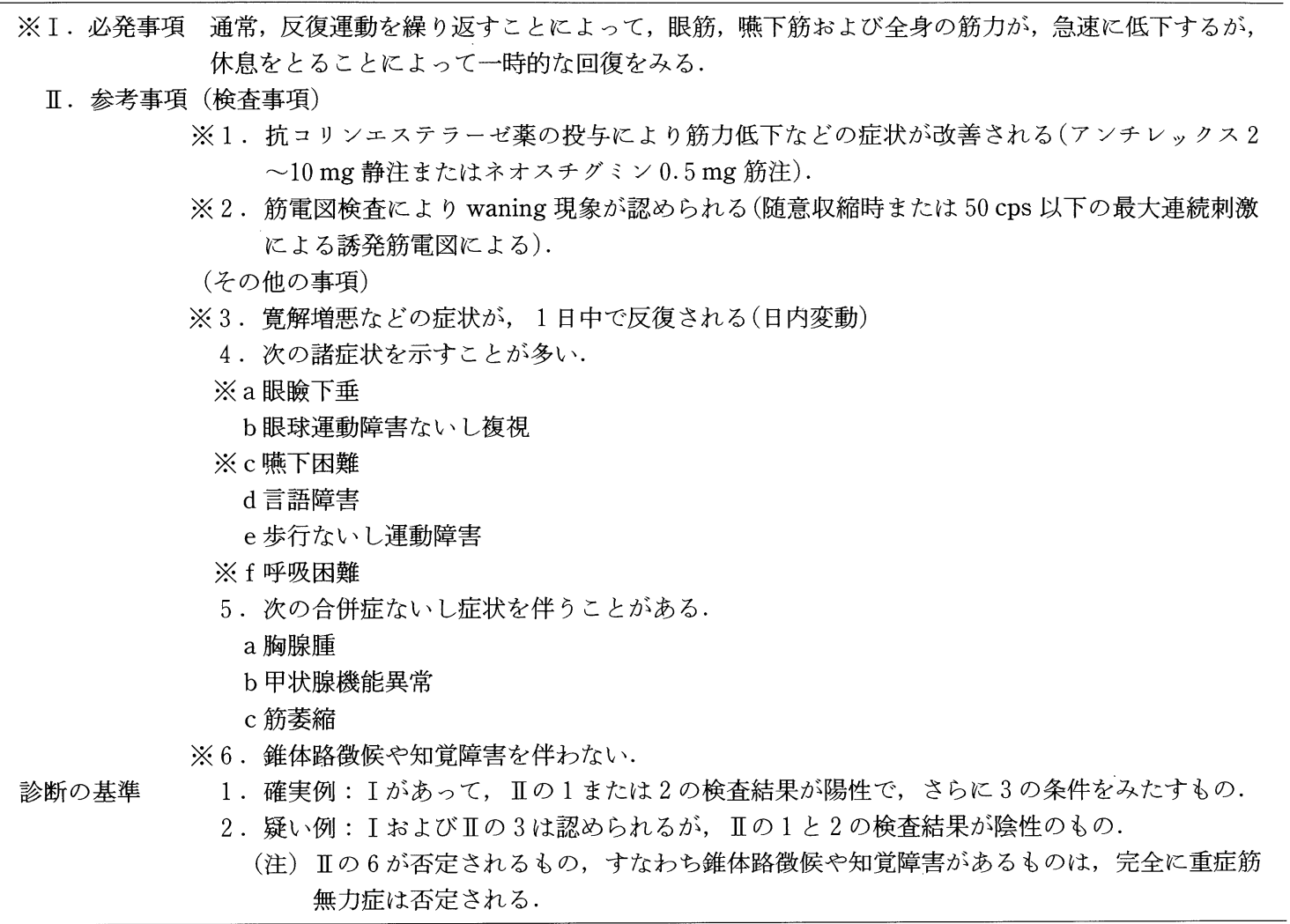


表 2 曣下障害の原因

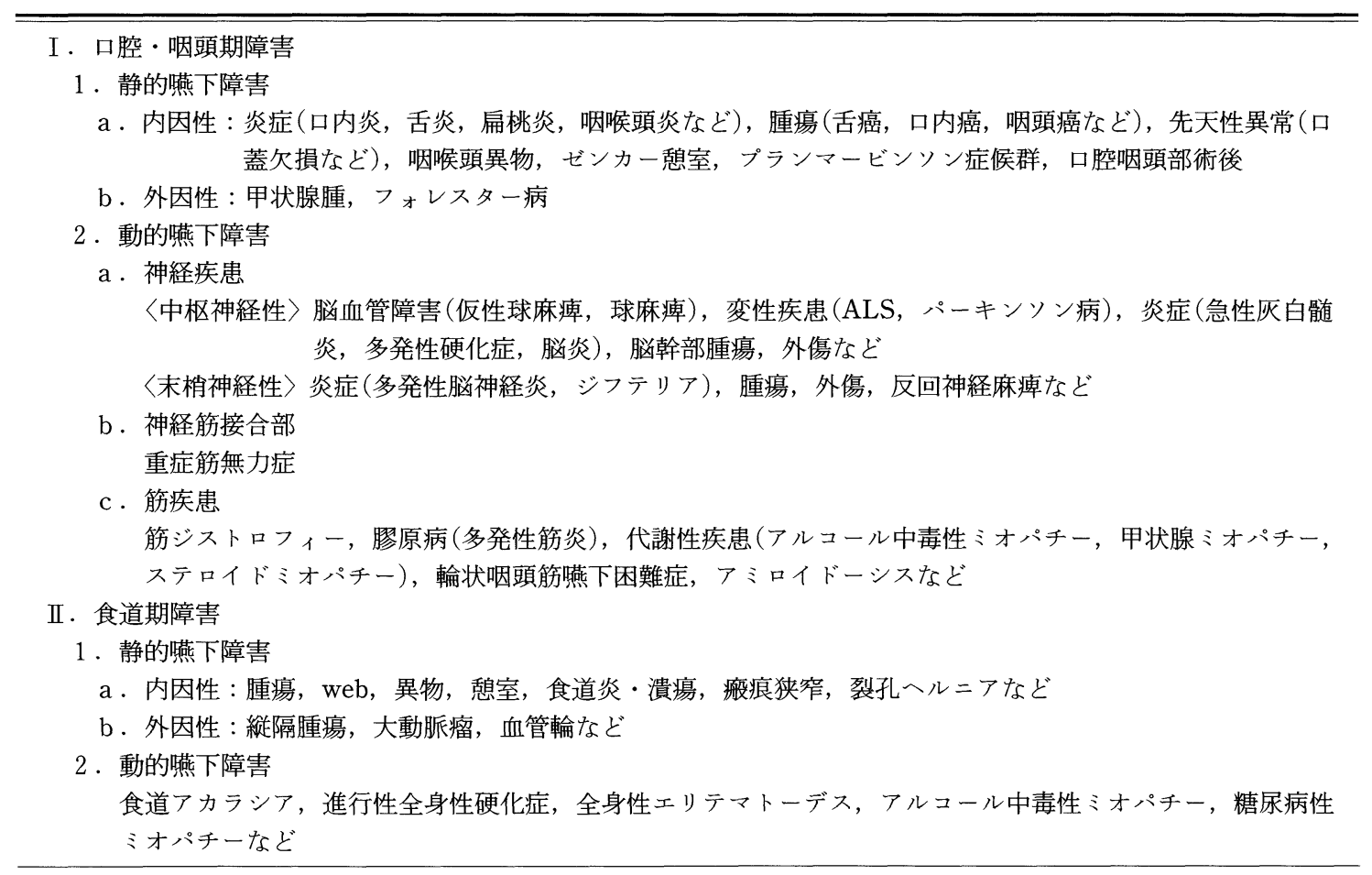

（田山二朗 : 19962)より転載）

重症筋無力症とは，随意筋の神経筋接合部に打积抗 アセチルコリンレセプター抗体の出現により，この部位 での刺激伝達が障害され4), 脱力を来しやすく, 運動の 持続で増悪し，休息にて回復するのを特徵とし，一種の 自己免疫疾患と考兄られている。一般に，胸腺腫の合併 が多く5), 疫学的には, 有病率 10 万人に対し 4 人の頻度 で，男女比は $1: 2$ と女性に多く，好発は20～30歳代と されている677). また，欧米では50～60歳代の男性に第 2 のピークを認めるとされているが，宇尾野らによると 本邦での 50 歳以後の高齢発病者は $7.3 \%$ にずず，高年 齢の発病は少ない1)。さらには，65歳以上の発病者は $2.2 \%{ }^{11)}$ で，71歳で発病した本症例は比較的まれな 1 例 であると言える。

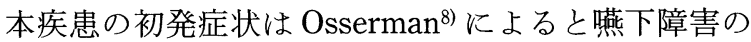
占める割合が $29 \%$, 全経過中では $60 \%$ と多く(表 3 ), 我 我耳鼻咽喉科医が遭遇する機会は多いものと考える。初 発症状として最も頻度が高いのは眼瞼下垂であり，その 占める割合は $57 \%$ と報告されている，本症例に扣いても， 初診時すでに軽微ながらも眼瞼下垂があり，その後の問 診にて平成 5 年 12 月, 初診時の約 6 力月前からの眼瞼下
表 3 重症筋無力症の症状

\begin{tabular}{|c|c|c|}
\hline 症 & $\begin{array}{l}\text { 初発症状亡しての } \\
\text { 発玩率 }(\%)\end{array}$ & $\begin{array}{l}\text { 全経過中での } \\
\text { 発現率 }(\%)\end{array}$ \\
\hline 眼瞼下垂 & 57 & 78 \\
\hline 外眼筋麻痺 & 48 & 70 \\
\hline 構語障害 & 29 & 56 \\
\hline 嚥下障害 & 29 & 60 \\
\hline 咀嚼障害 & 17 & 39 \\
\hline 呼吸困難 & 13 & 29 \\
\hline 顔面筋筋力低下 & 9 & 36 \\
\hline 頸部筋筋力低下 & 8 & 29 \\
\hline その他 & $4 \sim 24$ & $20 \sim 56$ \\
\hline
\end{tabular}

Osserman, 他 : 1971 ${ }^{8)}$ より改変

垂を自覚していたことが判明した. 重症筋無力症は眼筋 型と全身型に分けられ，與茄下障害は全身型に合併し，夕 方や食事の終わりに嚥下機能が悪化する筋疲労性が特徵 である ${ }^{9)}$.したがって, 口腔・咽頭の筋疲労により軟口 蓋と舌根部の挙上不全を生じた結果，鼻咽腔閉鎖不全を 呈し, 咽頭内圧の低下により食道への送り込みに障害が 起こる(10) 12). 食道に扣いては, 蠕動圧の低下や痤攣様 
の異常収縮により通過障害を生じるとされている 症例の初診時認められた食道造影所見もこうした異常収 縮によるものかもしれない.

本疾患でもっとも注意が必要な点は, 経過中筋力低下 が急に進行し，気道閉塞や呼吸困難に陥るクリーゼを生 じる事である. 本症例に沶いても入院翌日の夕方に気管 切開にて気道確保施行しているにも関らず，突然の自発 呼吸の停止を認めクリーゼによるものと考光られた. 入院当日に誤嚥性肺炎を生じたため気管切開施行し, PEEP 目的でたまたま人工呼吸を接続していたため大 事には至らなかったものの，クリーゼは生命予後に関与 する重篤な症状であり，本疾患の早急な診断と治療が必 要とされる. 本邦に拈いて本疾患のクリーゼの発症頻度 は14.8\% ${ }^{14)}$ とれている.

今回我々の症例では, 重症筋無力症の確定診断を得る までに，当科受診後約 2 週間といら長い経過を要した. このように, 診断に苦慮した理由には, 現病歴から食道 異物あるいは腫瘍の存在が強く疑われ，初診時の食道造 影所見に扣いても腫瘤の存在が疑われたことなどにより 器質的原因にのみとらわれたことが挙げられる.さらに， 年齢が高齢であり自己免疫疾患を疑いにくかったことや， 胸部 X-P や胸部 CT において胸腺腫を疑わす所見を得 なかったこと，気切执よびベンチレーターの接続にて患 者と十分なコミュニケーションをとれなかったこと，そ して眼瞼下垂や無力様顔貌に対する注意を欠いたことな ど，すなわち，與下障害の動的障害についての認識不足 であったことが原因と考える，近年高龃化社会を迎え脳 血管障害や痴呆などの疾患の数も増加していることから， 燕下障害の診断には嚥下のメカニズムを理解したらえで, 局所所見にのみこだわらず全身状態や症状の経過をしっ かりと追い, 器質的原因のみならず機能的原因の存在に ついても配慮することが重要であると考える.

\section{まとめ}

食事後の與下困難を主訴とした重症筋無力症の 1 例を 報告した．局所所見にとらわれることなく，全身疾患の 一症状として與下障害をとらえ，これを診察することが 重要であることを改めて認識した。

\section{参考文献}

1 ) 宇尾野公義, 平山宗宏, 里吉営二郎, 他 : 重症笳無力症の 成因と治療と予防洬する研究. 厚生省特定疾患重症筋無 力症調查研究班 S 47年度研究報告書 : 第 3 部 4, 1973.

2 ）田山二朗 : 嬹下機能と画像診断. 日気食会報 $47: 446 \sim 455$, 1996.

3 ）進 武幹：鱟下障害. JOHNS 5 : 537〜 541, 1989.

4) 高森正治 : 抗レセプタ一抗体と疾患 一重症筋無力症一. 免疫薬理 $8: 10 \sim 18,1990$.

5 ) Hohfeld $\mathrm{R}$ and Wekerle $\mathrm{H}$ : The thymus in myasthenia gravis. Neurol Clin $12: 331 \sim 336,1994$.

6 ) 井村裕夫, 尾形悦郎, 高久史磨, 他 : 神経筋接合部疾患. 最新内科学大系第71巻ミオパチー. 365〜 372頁, 中山書店, 東京, 1996.

7 ) 藤田拓男, 宮本昭正, 長沢俊彦, 他：神経疾患. 必修内科 学. 91 94頁, 南江堂, 東京, 1987.

8 ) Osserman $\mathrm{KE}$ and Genkins G : Studies in myasthenia gravis-review of twenty year experience in over 1200 patients. Mt Sinai J Med 38 : 497 537, 1971.

9) Hellemans J, Pelemans W and Vantrappen G : Pharyngoesophageal swallowing disorders and the pharyngoesophageal sphincter. Med Clin North Am 65 : 1149 1171,1981

10）城下 裕, 吉田充男, 吉田行雄, 他 : 消化管内圧計を用い た嚥下動態の解析一第 2 報 重症筋無力症での検討一. 臨床神経学 30：944～951, 1990.

11）丘村 熙，森 敏裕，稲木匠子：神経筋疾患による嚥下障 害. 日気食会報 $42 ： 400 \sim 406,1991$.

12）野崎園子, 松村 剛, 高橋正紀, 他：重症筋無力症患者に 抢ける嚥下一寛解・増悪による electroglottography の変 化一. 臨床神経学 $37: 841 \sim 843,1997$.

13) Huang $\mathrm{MH}$, King $\mathrm{KL}$ and Chien KY : Esophageal manometric studies in patients with myasthenia gravis. J Thorac Cardiovasc Surg $95: 281 \sim 285,1988$.

14）高森正治：重症筋無力症に扮けるわが国の現況 一全国調 查成績一. 神経内科 $32: 1 \sim 6,1990$.

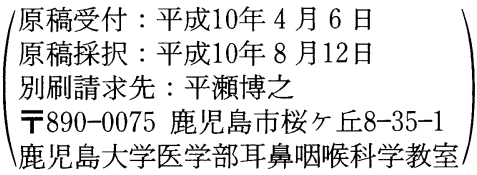

